\title{
A Validated Stability - Indicating HPLC Method estimation of Clonazepam In the bulk drug and Pharmaceutical Dosage Form
}

Pallavi Mangesh Patil ${ }^{1 *}$, Sagar Baliram Wankhede² and Praveen Digambar Chaudhari'

'P.E.Society's Modern College of Pharmacy Yamunanagar, Nigdi, Pune-411044 Maharashtra, India, 411044

${ }^{2}$ Padm. Dr.D.Y. Patil Institute of Pharmaceutical Sciences \& Research, Pimpri, Pune-411018, Maharashtra, India

\begin{abstract}
A rapid, accurate, linear, and sensitive RP-HPLC method has been developed and validated for estimation of Clonazepam in the bulk and Pharmaceutical Dosage Form. The chromatographic separation was performed on C18 Column $(250 \mathrm{~mm} \times 4.6 \mathrm{~mm}, 5$ $\mu \mathrm{m}$ particle size) using a mobile phase Acetonitrile: Methanol $(60: 40 \mathrm{v} / \mathrm{v})$ at flow rate of $1.0 \mathrm{ml} / \mathrm{min}$ and $30^{\circ} \mathrm{C}$ column temperature with the detection wavelength at $254 \mathrm{~nm}$. The Clonazepam (RT $6.11 \mathrm{~min}$ ). The linearity was performed in the concentration range of 5 to $25 \mu \mathrm{g} / \mathrm{ml}$ for Clonazepam R $\mathrm{R}^{2}$ 0.9993, Clonazepam. The percentage purity of Clonazepam was found to be $99-101 \%$. Precision (Inertday) of the system was found to be $0.48 \%$ Clonazepam and all the method was found to be specific and found to be within the limits of the acceptance criteria. The limit of detection was $0.092 \mu \mathrm{g} / \mathrm{ml}$ and limit of quantification was $0.97 \mu \mathrm{g} / \mathrm{ml}$. Clonazepam was found to be specific. The Proposed method has been validated for which were within the acceptance limit according to ICH guidelines. Forced degradation conditions of hydrolysis (neutral, acidic and alkaline), oxidation, photolysis and thermal stress, as suggested in the $\mathrm{ICH}$ guideline Q1A (R2). The drug showed instability in alkaline and oxide, while it remained stable in acid conditions.
\end{abstract}

Keywords: Clonazepam; Validation; Force degradation studies

\section{Introduction}

Clonazepam is a light yellow crystalline powder which is practically odourless. Literature survey states that Paroxetine hydrochloride and Clonazepam is official in IP [1], BP [2] with HPLC methods for the estimation individually. Clonazepam (CZ) in Figure 1 chemically, 5-(2-chlorophenyl)-7-nitro-2, 3-dihydro-1H-1, 4-benzodia zepin-2one (Figure1) belongs to the drug class benzodiazepines. Mechanism of action involves Allosteric interactions between central benzodiazepine receptors and gamma-minobutyric acid (GABA) receptors potentiate the effects of GABA. It's chemical formula and molecular weight is C15H10ClN3O3 and 315.7 [3-8], HPLC [3], LCMS based methods have been reported. A UV and Spectrophotometric methods was reported for the estimation of Paroxetine and Clonazepam in combined formulations [9-10]. But no stability-indicating assay method has been reported for the simultaneous estimation of Clonazepam in the presence of their degradants using the ICH [11-13] approach of stress testing. Therefore, the present work was aimed to develop a simple, rapid, precise, and accurate isocratic reversed-phase stability indicating HPLC method for estimation of Clonazepam in the bulk drug and tablet dosage forms. The developed method was validated as per ICH Guidelines.

\section{Materials and Methods}

All the reagents as Acetonitrile and Methanol (HPLC grade), were purchased from Merck Chemicals, India. Reference standard Clonazepam was procured from Reddy Hyderabad laboratories, India as gift samples.

\section{Instrumentation and chromatographic conditions}

Different kinds of equipment like Analytical weighing balance, HPLC system (SHIMADZU-SPD 20A), Injector (Rheodyne, $20 \mu \mathrm{l}$ ), Sonicator, $\mathrm{pH}$ meter, vacuum filter pump, Millipore filtration kit, mobile phase reservoir. Grace C18 ACME 9000, C18 reverse phase column of $250 \times 4.0 \mathrm{~mm}$ i.e., $5 \mu \mathrm{m}$ dimensions Detector: UV, D2 lamp, $254 \mathrm{~nm}$ Column Temperature: Controlled room temperature $\left(25^{\circ} \mathrm{C}\right)$ Injection: $20 \mu \mathrm{L}$ sample loop was used for Clonazepam with the help of mobile phase consisted of a mixture.

\section{Preparation of standard concentrations}

Accurately weighed quantity $(100 \mathrm{mg})$ of $\mathrm{CZ}$ respectively were transferred to $100.0 \mathrm{ml}$ volumetric flask, dissolved and diluted up to the mark with mobile phase. From this solution, $5.0 \mathrm{ml}$ was transferred to $50.0 \mathrm{ml}$ volumetric flask and diluted to the mark with mobile phase (concentration $100 \mu \mathrm{g} / \mathrm{ml}$ ) CZ respectively. The solution was mixed and filtered through $0.2 \mu$ membrane filter.

\section{Calibration standards CZ}

From standard stock solution CZ (100 ug/ml) final Concentration was made in ranges $5-25 \mu \mathrm{g} / \mathrm{ml}$.

\section{Method validation}

The validated HPLC method proposed according to ICH guidelines (ICH 1994, 1996). The following parameters were used for validation of the developed method.

Linearity: Linear relationship between peak area and concentration of the drugs were evaluated, making six measurements at concentration levels in the range of $5-25 \mu \mathrm{g} / \mathrm{ml}$.

Accuracy: Recovery studies were carried out by spiking three different known amounts of pure drug (at $80 \%, 100 \%$ and $120 \%$ of label claim) to the pre-analyzed powder (standard addition method). Hence, an accurately weighed quantity of pre-analyzed tablet $10 \mathrm{mg} \mathrm{CZ}$ to the pre-analyzed.

*Corresponding author: Pallavi Mangesh Patil, P.E.Society's Modern College of Pharmacy, Yamunanagar, Nigdi, Pune-411044, India, Tel: +91 09823720695 E-mail: pallavipatil2007@yahoo.com, psadanshio@yahoo.co.in

Received December 12, 2014; Accepted January 27, 2015; Published February 02, 2015

Citation: Patil PM, Wankhede SB, Chaudhari PD (2015) A Validated Stability-Indicating HPLC Method estimation of Clonazepamln the bulk drug and Pharmaceutical Dosage Form. Pharm Anal Acta 6: 332. doi:10.4172/21532435.1000332

Copyright: ( 2015 Patil PM, et al. This is an open-access article distributed under the terms of the Creative Commons Attribution License, which permits unrestricted use, distribution, and reproduction in any medium, provided the original author and source are credited. 


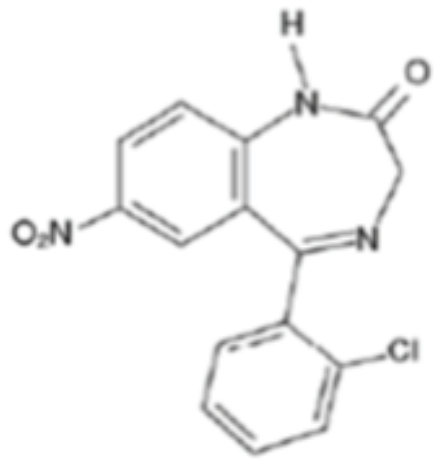

Figure 1: Chemical Structure of Clonazepam

Precision: The precision of the method was verified by repeatability and intermediate precision studies. Repeatability studies were performed by analysing the table sample six times at $100 \%$ of test concentration on the same day. The intermediate precision of the method was checked by repeating studies on three different days.

Limit of detection and quantitation: In order to estimate the limit of detection (LOD) and limit of quantitation (LOQ) linear were separately determined based on the standard deviation $(\sigma)$ of the response and the slope (S) of the calibration curve and using the formula $\mathrm{LOD}=3.3 \sigma / \mathrm{S}$ and $\mathrm{LOQ}=10 \sigma / \mathrm{S}$, the $\mathrm{LOD}$ and $\mathrm{LOQ}$ for $\mathrm{CZ}$ was estimated.

Robustness: To evaluate the robustness of the proposed method, small but deliberate variations in the optimized method parameters were done. The effect of change in flow rate and mobile phase ratio on retention time and tailing factor were studied. The solution containing $100 \mu \mathrm{g} / \mathrm{ml}$ of CZ was injected (in triplicate) into sample injector of HPLC three times under the varied conditions.

\section{Stability}

\section{Stability in sample solutions}

Sample solution of CZ $(100 \mu \mathrm{g} / \mathrm{ml})$ was prepared and was kept at room temperature $\left(30 \pm 20^{\circ} \mathrm{C}\right)$ protected from day light. The sample solution was assayed after $20 \mathrm{~min}, 1 \mathrm{~h}, 2 \mathrm{~h}, 4 \mathrm{~h}, 8 \mathrm{~h}$ and $24 \mathrm{~h}$ and hence results of the remaining analysis times were compared with it. The percent label claim and the RSD values are shown in Table 1 . The result of solution stability is stable for 24 hours.

\section{System suitability}

To ascertain resolution and reproducibility of proposed chromatographic system for estimation of $\mathrm{CZ}$ in Pharmaceutical dosage form, system suitability parameters like tailing factor (T), resolution $(\mathrm{R})$ and column efficiency (number of theoretical plates, $\mathrm{N}$ ) were studied. From stock solution D, appropriately diluted with mobile phase to obtain $100 \mu \mathrm{g} / \mathrm{ml} \mathrm{CZ}$. The diluted standard solutions were filtered through $0.2 \mu$ membrane filter.

\section{Force degradation studies}

In order to evaluate the stability indicating property of the developed HPLC method stress studies were carried out under ICH recommended conditions. Intentional degradation was tried by exposing the tablet sample to following stress conditions: acid $(0.1$ $\mathrm{N} \mathrm{HCl}$ at $\left.60^{\circ} \mathrm{C}\right)$, base $\left(0.1 \mathrm{~N} \mathrm{NaOH}\right.$ at $\left.60^{\circ} \mathrm{C}\right)$, oxidation $\left(3 \% \mathrm{H}_{2} \mathrm{O}_{2}\right.$ at $\left.60^{\circ} \mathrm{C}\right)$, and heat $\left(60^{\circ} \mathrm{C}\right)$, and UV light $(254 \mathrm{~nm})$. Ability of the proposed method to measure the analyte response in presence of its degradation products was studied.

\section{Results and Discussion}

\section{Optimization of separation conditions}

Different mobile phases containing Acetate buffer, Phosphate buffer, Methanol and Acetonitrile in different ratio, and various $\mathrm{pH}$ were tried and finally Acetonitrile: Methanol in the ratio (60:40 v/v) was selected as an appropriate mobile phase that resulted in good resolution and acceptable system suitability parameters for CZ was delivered at a flow rate of $1 \mathrm{ml} / \mathrm{min}$ with detection wavelength $254 \mathrm{~nm}$ for $\mathrm{CZ}$, The injection volume was $20 \mu \mathrm{l}$. Analysis was performed at a temperature of $30^{\circ} \mathrm{C}$, which shown in Figure 3 .

\section{Sample solution}

The corresponding chromatograms were recorded and area of each peak for $\mathrm{CZ}$ was measured at $254.0 \mathrm{~nm}$. Amount of $\mathrm{CZ}$ in sample (mg) was calculated by comparing the mean peak area of standard and sample solution.

Results of analysis of sample laboratory mixture are shown in Tables 2 and 3 .

\section{System suitability}

For system precision six replicate injections of standard solution were given, tailing factor $(\mathrm{T})$, and column efficiency (number of theoretical plates, N) were studied. For CZ was recorded for each injection shown in Table 7.

\section{Validation of the method}

Linearity of response: A linear relationship was observed between peak area and concentration in the range of $5-25 \mu \mathrm{g} / \mathrm{ml} \mathrm{CZ}$ respectively. The correlation coefficients for the calibration curve were found to be 0.9993 , for CZ. Mean peak areas for CZ at selected wavelength are shown in Table 2 and Figure 2.

Precision of the assay: Repeatability and reproducibility of the proposed method was determined by intra-day and inter-day precision studies. The Tablet was assayed three times on the same day (intra-day) and on three consecutive days (inter-day). The results of precision studies were expressed in terms of relative standard deviation (RSD) less than 2 of the percent label claim determined by developed method shown in Table 4.

Limit of Detection (LOD) and Quantification (LOQ): The limits of detection was $0.92 \mu \mathrm{g} / \mathrm{ml}$ for $\mathrm{CZ}$ and limit of quantification were $0.97 \mu \mathrm{g} / \mathrm{ml}$ for CZ respectively shown in Table 5 .

Accuracy: The results of accuracy study are expressed in terms of percent recovery. The percent recovery at three levels $(80 \%, 100 \%$ and $120 \%$ ) was found to be in the range of 98-102\% Results of recovery studies are shown in Table 2 and 3.

\begin{tabular}{|c|c|}
\hline \multicolumn{2}{|c|}{ Clonazepam (CZ) } \\
\hline Concentration $(\boldsymbol{\mu g} / \mathbf{m l})$ & Mean Peak Area \\
\hline 0 & 0 \\
\hline 5 & 344,337 \\
\hline 10 & 452,756 \\
\hline 15 & 4226,664 \\
\hline 20 & 8518,328 \\
\hline 25 & 879,1890 \\
\hline
\end{tabular}

Table 1: Standard Calibration Table for Clonazepam. 
Citation: Patil PM, Wankhede SB, Chaudhari PD (2015)A Validated Stability-Indicating HPLC Method estimation of Clonazepamln the bulk drug and Pharmaceutical Dosage Form. Pharm Anal Acta 6: 332. doi:10.4172/21532435.1000332

Page 3 of 5

\begin{tabular}{|c|c|c|c|c|}
\hline Level of recover & Weight of tablet taken (mg) & Amount of drug added (mg) CZ & Amount of drug recovered $(\mathrm{mg}) \mathrm{CZ}$ & \% Recovery CZ \\
\hline \multirow{3}{*}{$80 \%$} & 10 & 8 & 18.01 & 100.01 \\
\hline & 10 & 8 & 18.21 & 100.27 \\
\hline & 10 & 8 & 18.00 & 100.02 \\
\hline \multirow{3}{*}{$100 \%$} & 10 & 10 & 19.11 & 99.91 \\
\hline & 10 & 10 & 19.13 & 99.95 \\
\hline & 10 & 10 & 19.17 & 99.97 \\
\hline \multirow{3}{*}{$120 \%$} & 10 & 12 & 22.02 & 100.02 \\
\hline & 10 & 12 & 22.10 & 100.10 \\
\hline & 10 & 12 & 21.97 & 99.95 \\
\hline
\end{tabular}

Table 2: Results of Accuracy Studies.

\begin{tabular}{|c|c|c|c|}
\hline Mean & 100.18 & 99.94 & 100.04 \\
\hline S.D. & \pm 0.5812 & \pm 0.4178 & \pm 0.219 \\
\hline C.V. & \pm 0.5810 & \pm 0.4170 & \pm 0.2222 \\
\hline
\end{tabular}

Table 3: Results of Statistical Validation for Accuracy Studies.

\begin{tabular}{|c|c|c|c|}
\hline \multicolumn{4}{|c|}{ Intra-day Precision } \\
\hline Drug & \% Mean* & S. D. & C. V. \\
\hline CZ & 99.98 & \pm 0.4189 & 0.4812 \\
\hline \multicolumn{4}{|c|}{ Inter-day Precision } \\
\hline CZ & 99.91 & \pm 0.3714 & 0.3516 \\
\hline
\end{tabular}

Table 4: Results of Precision.

\begin{tabular}{|c|c|}
\hline Parameter & $\mathrm{CZ}$ \\
\hline Limit of Detection $(\mu \mathrm{g} / \mathrm{ml})$ & 0.92 \\
\hline Limit of Quantification $(\mu \mathrm{g} / \mathrm{ml})$ & 0.97 \\
\hline
\end{tabular}

Table 5: LOD and LOQ of CZ.

Robustness: To evaluate the robustness of the proposed method, small but deliberate variations in the optimized method parameters were done. The effect of change in flow rate and mobile phase ratio on retention time and tailing factor were studied. The solution containing $25 \mu \mathrm{g} / \mathrm{ml}$ of $\mathrm{CZ}$ was injected (in triplicate) into sample injector of HPLC 3 times under the varied conditions. Robustness data is given in Table 6.

Stability: The stability evaluation in sample solutions (constituted with methanol) was performed up to $24 \mathrm{~h}$. The sample solutions placed in the autosampler at room temperature were analysed periodically at $1,2,4,8$ and $24 \mathrm{~h}$. The results are shown in Table 7. The peak areas of each drug were not considerably different from each other. Moreover, RSD value of each sample was $<1 \%$.

The corresponding chromatogram was recorded and area of each peak for CZ at $254.0 \mathrm{~nm}$. Amount of CZ in sample (mg) was calculated by comparing the mean peak area of standard and sample solution.

Assay of tablet: The resulting mixture of Tablet dosage form was centrifuged at $3500 \mathrm{rpm}$ for $20 \mathrm{~min}$. After centrifugation $20 \mu \mathrm{l}$ of this mixture was injected into the chromatograph. The resulting solution was mixed and filtered through Whatman filter paper and to get approximate concentration and to obtain final concentration of 100 $\mu \mathrm{g} / \mathrm{ml} \mathrm{CZ}$. The diluted solution was filtered through $0.20 \mu \mathrm{m}$ filter.

The corresponding chromatograms were recorded and area of each peak for $\mathrm{CZ}$ was measured at $254.0 \mathrm{~nm}$. Amount of $\mathrm{CZ}$ in sample (mg) was calculated by comparing the mean peak area of standard and sample solution are shown in Table 8.

Force degradation studies: In the forced degradation studies CZ

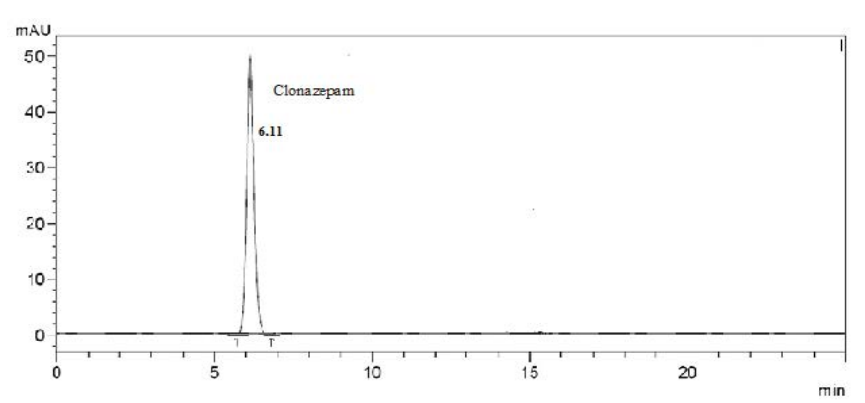

Figure 2: Typical chromatogram of (RT $6.11 \mathrm{~min})$.

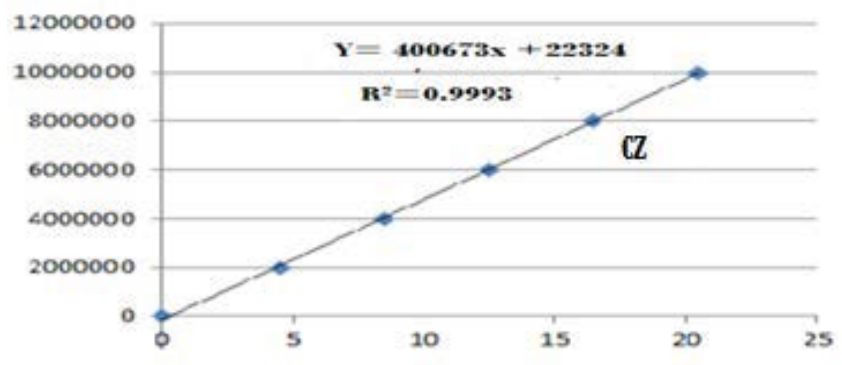

Figure 3: Standard Calibration Curve for CZ.

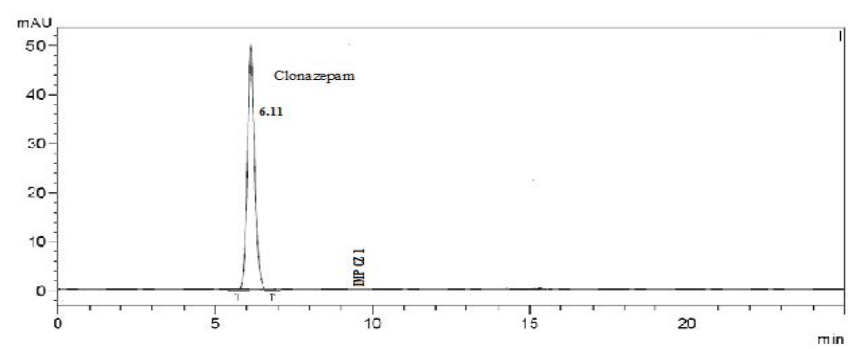

Figure 4: Chromatogram of $0.1 \mathrm{M} \mathrm{HCl}$ Treated Tablet Sample.

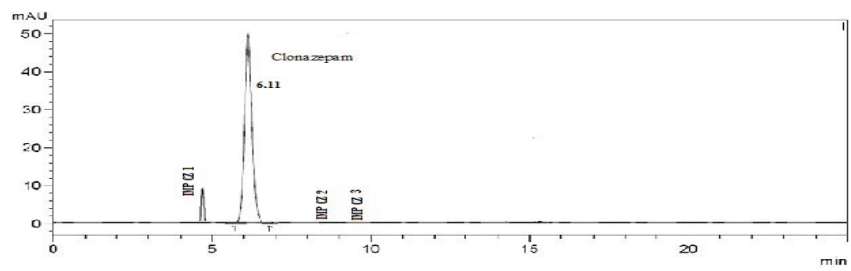

Figure 5: Chromatogram of $0.1 \mathrm{M} \mathrm{NaOH}$ Treated Tablet Sample. 


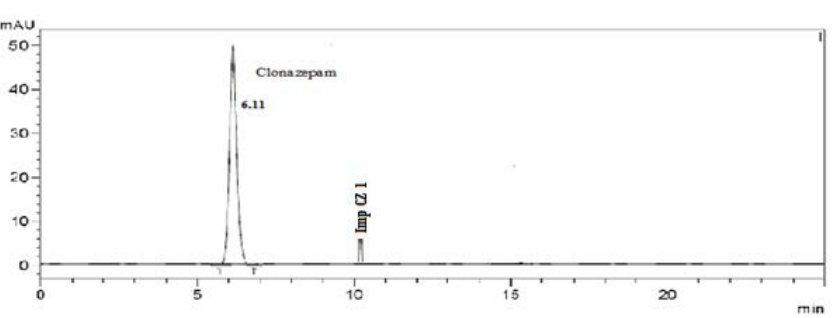

Figure 6: Chromatogram of $\mathrm{H}_{2} \mathrm{O}_{2}(3 \%)$ Treated Tablet Sample.

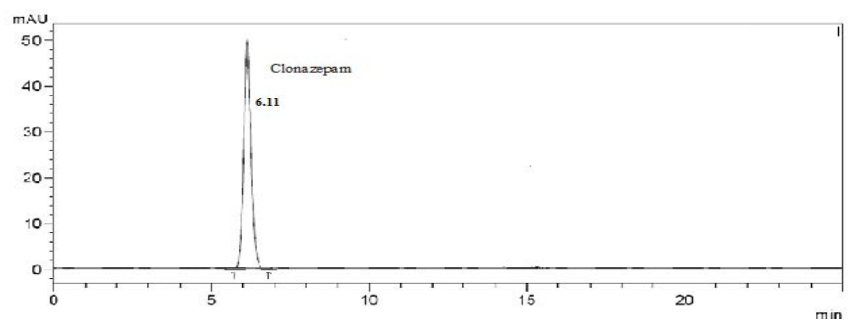

Figure 7: Chromatogram of Dry Heat Treated Tablet Sample.

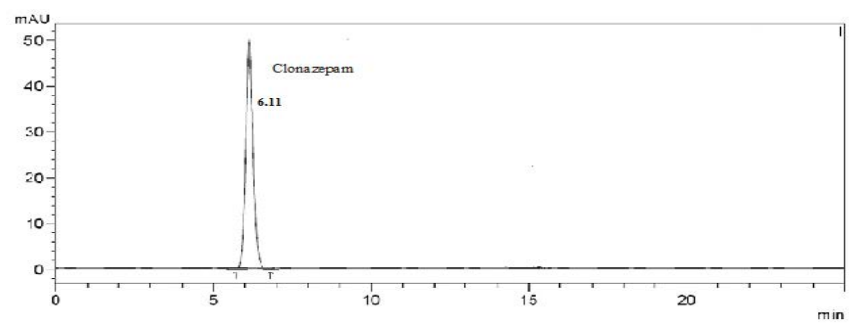

Figure 8: Chromatogram of UV Radiation Treated Tablet Sample.

\begin{tabular}{|c|c|c|c|}
\hline \multirow[b]{2}{*}{ Factor } & \multicolumn{3}{|c|}{ Chromatographic Changes } \\
\hline & Level & Retention time & Tailing factor \\
\hline Flow Rate(mL/min) & & CZ & $\mathrm{CZ}$ \\
\hline 0.9 & -0.1 & 6.12 & 1.15 \\
\hline 1.0 & 0 & 6.11 & 1.16 \\
\hline \multirow[t]{3}{*}{1.1} & +0.1 & 6.14 & 1.18 \\
\hline & Mean & 6.13 & 1.16 \\
\hline & S.D. & \pm 0.2118 & \pm 0.2412 \\
\hline $\begin{array}{l}\text { Mobile Phase ( } \pm 1 \mathrm{ml} \text { changing } \\
\text { Acetonitrile: Methanol) }\end{array}$ & Level & $\mathrm{CZ}$ & $\mathrm{CZ}$ \\
\hline $59: 39$ & -1.0 & 6.10 & 1.17 \\
\hline $60: 40$ & 0 & 6.11 & 1.15 \\
\hline \multirow[t]{3}{*}{$61: 41$} & +1.0 & 6.12 & 1.16 \\
\hline & Mean & 6.11 & 1.16 \\
\hline & S.D. & \pm 0.2189 & \pm 0.1446 \\
\hline
\end{tabular}

Table 6: Results of Robustness Studies

were found to degrade under acidic (0.1 M HCL) and oxidative (3\% $\mathrm{H}_{2} \mathrm{O}_{2}$ ) stress conditions employed. However it was found to be stable to the alkaline $(0.1 \mathrm{M} \mathrm{NaOH})$ and unstable in photo $(240 \mathrm{~nm})$ degradation, thermal $\left(60^{\circ} \mathrm{C}\right)$ and neutral conditions employed. The results for forced degradation studies are included in Tables 9 and 10. Typical chromatography obtained for $\mathrm{CZ}$ under different stress conditions are shown in Figures 4-8. The developed HPLC method could effectively resolve the drugs from their degradation products which confirm the stability indicating power of the developed method.

\section{Conclusion}

The present HPLC method for determination of $\mathrm{CZ}$ was proved to be simple, rapid, precise, accurate and robust in their pharmaceutical dosage and validated as per ICH guidelines. Moreover, $\mathrm{CZ}$ was found stable in the sample solutions placed at room temperature up to $24 \mathrm{~h}$. accordingly the proposed analytical procedure with detection time of 10 min can be used for reliable determination of $\mathrm{CZ}$ in bulk and tablet.

The Force degradation studies method was found to be simple, sensitive, selective, and suitable for determination of $\mathrm{CZ}$ in presence of its degradation products $\mathrm{CZ}$ is instable in alkaline and acidic and stable in thermal and photo light. Statistical analysis proved that the method is repeatable, reproducible, accurate and specific for the analysis of CZ. The developed HPLC method which confirms the stability indicates power of the developed method.

As the method in cost effective and less time consuming, thus, it can represent another good alternative for the already existing HPLC methods.

\begin{tabular}{|l|c|c|}
\hline 1. & Tailing factor (T) & 1.16 \\
\hline 2. & No. of theoretical plates $(\mathrm{N})$ & 7330 \\
\hline 3. & $\begin{array}{c}\text { System precision } \\
\text { \% RSD for peak area) }\end{array}$ & 0.549 \\
\hline 4. & $\begin{array}{c}\text { Method precision } \\
(\% \text { RSD for peak area) }\end{array}$ & 0.358 \\
\hline
\end{tabular}

Table 7: System Suitability Parameters.

\begin{tabular}{|l|c|c|c|}
\hline Sr.No & $\begin{array}{c}\text { Weight of tablet taken } \\
\mathbf{C Z}(\mathbf{m g})\end{array}$ & $\begin{array}{c}\text { Amount of drug } \\
\text { estimated CZ } \mathbf{( m g )}\end{array}$ & \% Label Claim \\
\hline 1 & 100 & 99.98 & 99.97 \\
\hline 2 & 100 & 99.97 & 99.96 \\
\hline 3 & 100 & 100.02 & 100.01 \\
\hline 4 & 100 & 100.13 & 100.12 \\
\hline 5 & 100 & 99.86 & 99.85 \\
\hline 6 & 100 & 99.72 & 99.71 \\
\hline & & Mean & 99.96 \\
\hline & & S.D. & \pm 0.5242 \\
\hline & & C.V. & \pm 0.5458 \\
\hline
\end{tabular}

*denotes average of three determinations

Table 8: Results of Analysis of Tablet.

\begin{tabular}{|l|c|c|c|}
\hline Sr. No. & Stress Condition & $\begin{array}{c}\text { Percent assay of active } \\
\text { substance }(\mathrm{CZ})\end{array}$ & $\begin{array}{c}\text { RT Value of degraded } \\
\text { product }\end{array}$ \\
\hline 1. & Acid $(0.1 \mathrm{M} \mathrm{HCl})$ & 98.60 & 10.1 \\
\hline 2. & Alkali $(0.1 \mathrm{M} \mathrm{NaOH})$ & 97.53 & $4.8,8.3,9.5$ \\
\hline 3. & Oxide $\left(3 \% \mathrm{H}_{2} \mathrm{O}_{2}\right)$ & 98.76 & 10.2 \\
\hline 4. & Heat $\left(60^{\circ} \mathrm{C}\right)$ & 99.82 & \\
\hline 5. & UV $(240 \mathrm{~nm})$ & 99.98 & -- \\
\hline
\end{tabular}

Table 9: Results of Degradation Study.

\begin{tabular}{|c|c|c|c|c|}
\hline Time & $\begin{array}{c}\text { Amount of drug } \\
\text { estimated } \mathrm{CZ}\end{array}$ & $\%$ Label Claim* & S.D. ( \pm ) & \% C.O.V. \\
\hline $20 \mathrm{~min}$ & 99.98 & 99.88 & 0.376 & 0.452 \\
\hline $1 \mathrm{~h}$ & 99.78 & 99.67 & 0.311 & 0.389 \\
\hline $2 \mathrm{~h}$ & 99.04 & 99.89 & 0.378 & 0.392 \\
\hline $4 \mathrm{~h}$ & 100.00 & 10.00 & 0.408 & 0.455 \\
\hline $12 \mathrm{~h}$ & 100.10 & 10.07 & 0.455 & 0.478 \\
\hline $24 \mathrm{~h}$ & 99.98 & 99.91 & 0.377 & 0.394 \\
\hline
\end{tabular}


Citation: Patil PM, Wankhede SB, Chaudhari PD (2015)A Validated Stability-Indicating HPLC Method estimation of Clonazepamln the bulk drug and Pharmaceutical Dosage Form. Pharm Anal Acta 6: 332. doi:10.4172/21532435.1000332

Page 5 of 5

\section{Acknowledgments}

The authors are thankful to Reference standards of clonazepam were procured as gift samples from Dr.Reddys Laboratories, Hyderabad, India. Authors are also thankful to Modern college of Pharmacy, Nigdi Pune for carrying out some part of the analytical work.

\section{References}

1. The Indian Pharmacopeia (2014) Government of India, Delhi 2:1435-2439.

2. British pharmacopeia (2014) Stationary office, London: Medicines and Health care products regulatory agency: 1-2: 587-588.

3. Meghana D, Lahari K, KS Kumari, Prakash K (2012) Development and Validation of RP-HPLC Method for Simultaneous Estimation of Clonazepam and Propranolol Hydrochloride in Bulk and Pharmaceutical Dosage Forms. Inventi Rapid: Pharm Analysis \& Quality Assurance 3: 12-16.

4. Chusena N, D Rao Garikapati, Usha P (2012) Development And Validation of An RP-HPLC Method for the Simultaneous Determination of Escitalopram Oxalate And Clonazepam in Bulk and its Pharmaceutical Formulations, International Current Pharmaceutical Journal 1:8: 193-198.

5. Sai T, Sakinala A, Shilpa C, Bala Vaidya S, J Rao (2012) Development and Validation of A RP-HPLC Method for Simultaneous Estimation of Propranolol $\mathrm{HCL}$ and Clonazepam in Bulk and Pharmaceutical Dosage Forms , International Research Journal of Pharmacy $3: 13-19$
6. Chakole R, Charde M, N.Bhavsar, Marathe RP (2012) Simultaneous Estimation of Escitalopram and Clonazepam by RP-HPLC in Pharmaceutical Formulations. International Journal of Phytopharmacy 2: 25-29.

7. Moinuddin R Syed, Seema hashmi, Jitendra B Naik (2010) UV Spectrophotometric Method Development and Validation for Determination of Paroxetine Hydrochloride in Pharmaceutical Dosage Form, International Journal of Pharmacy And Pharmaceutical Sciences 2: 43-45.

8. MC Sharma, Smita Sharma (2010) Validated Simultaneous Spectrophotometric Estimation of Paroxetine HCL Bulk and Tablet Dosage Form Using Ferric Chloride, J. Optoel and Biomed. Mater 2: 185-89.

9. Janvika M, Hardik A Bhalodiya, Parula B Patel (2012) UV-Spectroscopic Method for Simultaneous Estimation of clonazepam and paroxetine Hydrochloride Hemihydrate in Combined Pharmaceutical Formulation, Inventi 21:333.

10. Sheeja VK, Swapna AS, Sosamma CE, Kumar P (2014) Method Development and Validation for the Simultaneous Estimation of Clonazepam and Paroxetine in Combined Dosage form using Colorimetry, Asian journal of Research in chemistry 7: 48 .

11. Text on Stability Testing of new Drug Substances and Products Q1A (R2) (2003) In ICH, Harmonised Tripartite Guideline.

12. Text on validation of analytical Procedures Q2 (R1) (2005) In: ICH, Harmonised Tripartite Guideline. 